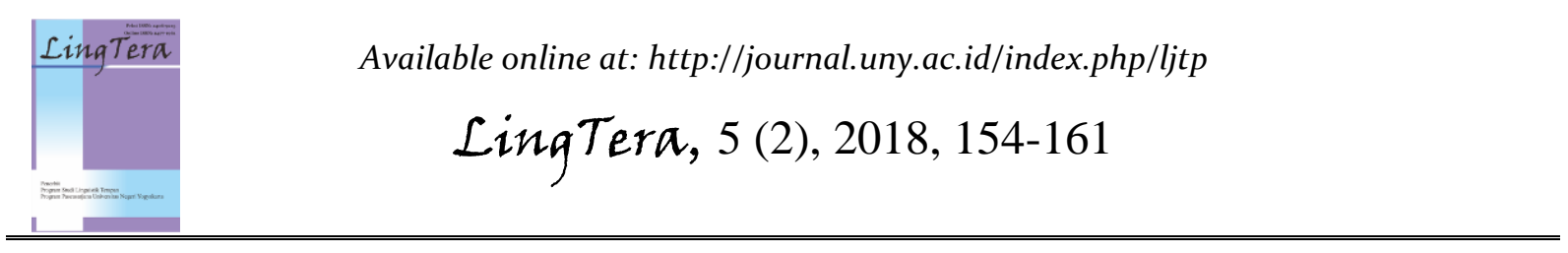

\title{
Evaluation of English language materials: One junior high school in Yogyakarta
}

\author{
Godlove Elioth Kiswaga ${ }^{1 *}$, Anita Triastuti ${ }^{2}$ \\ ${ }^{1}$ Department of Education, The Mwalimu Nyerere Memorial Academy. \\ P.O. BOX 9193 Dar es Salaam, Tanzania \\ ${ }^{2}$ Department of English Language Education, Universitas Negeri Yogyakarta. \\ Jalan Colombo No. 1, Karangmalang, Yogyakarta 55281, Indonesia. \\ * Coresponding Author. E-mail: kiswagagodlove8@gmail.com \\ Received: 23 October 2018; Revision: 16 November 2018; Accepted: 31 December 2018
}

\begin{abstract}
Teaching language in this global era demands mostly the creativity of the teachers, this is because in 21th century, students need to be critical thinkers, creative, communicative and collaborative. Therefore, the creativity of the teacher is manifested by evaluating the multiple resources and adapting or adopting them based on the contextualized learning situation including individual differences, styles and learners needs. It is also essential for the teacher to integrate the four macro skills in teaching language in order to make the students more communicative and collaborative. Hence, this paper presents the evaluation of the language teaching resources before and during applying them to the classroom contexts. The data were collected by document review, classroom observation and interview with the secondary school teacher. The data were analyzed qualitatively through interactive model. There is variation of the results based on the techniques of data collection. The interview shows that theoretically the teacher is creative to make the materials for students. Meanwhile, the observation and document review findings show that there is a need of improvement on the way to evaluate and use the English materials based on the context. Finally, we suggest that the theoretical knowledge from interview should be implemented practically in class and in evaluating the textbooks in order to adopt or adapt by adding or removing some materials to make English textbooks match with students contexts..
\end{abstract}

Keywords evaluation, adapting, adopting, macro skills in English language teaching.

How to Cite: Kiswaga, G., \& Triastuti, A. (2018). Evaluation of English language materials: One junior high school in Yogyakarta. LingTera, 5(2), 154-161. doi:https://doi.org/10.21831/lt.v5i2.22317

https://doi.org/10.21831/lt.v5i2.22317

\section{INTRODUCTION}

In this $21^{\text {th }}$ century, there is a high demand for creativity to the language teachers. The creativity is needed because teachers have to evaluate the existing language resources and adapt them by adding multiple resources to cater individual learner's style and the context of learning environment. This creativity is also manifested through integration of the four macro skills in teaching and learning activities. Therefore, integrating the four skills and evaluation of the resources are essential to mould the students to be creative, collaborative, critical thinkers and communicative. All these are demanded in order to make the learners of English language survive in this global era. Materials evaluation refers to an attempt to measure the value of the materials with the aim to predict whether or not the materials will be suitable to the learner's needs, style, level of language proficiency and context. Ultimately the students understand and enjoy the learning process (Tomlinson, 2011). According to Tomlinson (2011) the language materials should consider the learning style of learners such as; visual, auditory, kinesthetic, studial, experiential, analytic, dependant and independent learners.

It is essential to evaluate the language materials because each language learning context is unique. Karimnia and Jafari (2017) support this view by expanding that, the learning situations differ in terms of the study course, methodology, materials and procedures of teaching. Similarly McDonough, Shaw \& Masuhara (2012), explain different factors which necessitate evaluation of language material; 


\section{LingTera, 5 (2), 2018 - 155 \\ Godlove Elioth Kiswaga, Anita Triastuti}

First, the needs of the learners, these needs include the language proficiency level of the learners, the individual learning styles of the learners, age, what do they want to achieve and many other learner's needs. The authors also describe that evaluation of the materials should be done to make sure the materials match with the global categorization of learners. Examples, English for Young Learners, English for Specific Purpose, English for Academic Purpose, English as a Foreign Language and English for Second Language. These points are supported by Ahamed (2017) and Jafari and Karimia (2017) who emphasize on the needs of the learners as the basic reason to evaluate the material.

Secondly, the language position in education setting also is important factor for material evaluation. The setting includes several issues like, the status of the language and how it is viewed at given setting, whether it is the first language, second language or foreign language, the materials used will be different. Ahmed (2017) elaborates this factor under the umbrella of global factors. He adds that, there is global uniformity of the way teaching language should be done to match with the global era. Therefore, the materials should be evaluated to make the learners match with the global situation in inner circle, outer circle or expanded circle. Hence, if it is an era of communicative approach the materials have to match with communicative approach.

Thirdly, goals and objectives planned to be implemented in classroom context demand for evaluation of the materials. For example whether the learners need to be able to communicate after learning language or they just want to master the structure of language. The fourth point is whether the materials match with the principles and the approaches used. For example in communicative language teaching the materials must enable a person to be able to communicate using language.

Fifth materials and language resources should be evaluated to match with type of the syllabuses used at a given context. According to McDonough, et al. (2012), there are six types of language syllabuses, namely structure or grammatical syllabus, functional or notional syllabus, skilled based, topic based, task based and situational syllabus, each of these syllabuses require its unique materials and resources to be implemented effectively. Ahmed (2017), Karimnia and Jafari (2017) support that materials should be evaluated to match with the curriculum and syllabus used at the given institution.
However, Ahmed adds that materials should be evaluated to check if they are authentic and useful to the learners.

One of the factors to consider in evaluation of the materials is the integration of the four skills in teaching English language. It is essential to integrate the four skills in language learning in this global era, integrating the four skills makes the students match with status quo of the students in 21th century. The language students need to be critical thinker, creative, communicative and collaborative. Hence, the language students cannot be competent in these four characteristics if the four macro language skills are taught in isolation.

Similarly, different scholars have different views about the importance of integrating the four skills in language learning. However, most of their views are similar with little disparity. Integrating the four skills as essential to make the students more communicative has been supported by Rahman and Akhter (2017), Akram and Malik, (2010), Hinkel (2010), Klimova (2014), McDonough, et al. (2012), Sadiku (2015) and Tajzad and Ostovar-Namaghi (2014).

However, Akram and Malik (2010) and McDonough, et al. (2012) add that integrating the four skills makes language learners competent in solving real world problems related to language, this can be done through, task based language learning, group work, pair work, project based language learning, problem based and role play. All these strategies are just possible by integration the four skills in language learning. The view of their points goes beyond normal communication since it includes creativity, critical thinking and collaboration.

Klimova (2014) and Mcdonough et al. (2013) also explain the vital role played by integrating the four macro language skills to make learning more practical and authentic. This point is very essential since McDonough, et al. (2012) emphasizes that, isolating the four skills will only prepare the language students to pass examinations. Also, Klimova (2014) points one unique point which is very important, he explains that integrating the four skills in language is more inclusive in consideration to individual learning style of the learners since both introverts and extroverts will be involved in teaching and learning activities. Introverts can listen and read while extroverts can practice speaking and analytic and visual learners can see the written constructed sentences. 


\section{LingTera, 5 (2), 2018 - 156}

\section{Godlove Elioth Kiswaga, Anita Triastuti}

Moreover, Tajzad and Ostovar-Namaghi (2014) and Sadiku (2015) explain the importance of integrating the four skills with the view that, it increases confidence and reduces anxiety and stress in the language learning process. Their views are valid since stress and anxiety affect students negatively. Therefore, through collaboration in tasks and problem solving with listening, reading, writing and speaking activities, students will feel better since the class is changed into normal daily activities as they do outside classes. Generally, integrating the four skills is very important in language learning. Its necessity is supported by concluding points from the following authors; Sadiku (2015) explains that, the four macro skills are separate but bound with inseparable bound while McDonough, et al. (2012) explains that in daily life, language is not used with only one skill but language is normally used with more than one skills.

However, evaluation of the resources based on the student's context is not paid attention by many teachers of English. Most of the English teachers teach by using the textbooks without evaluating them. As a result students do not learn English effectively from multiple and innovative resources needed in this era.

Therefore, this study discusses the importance of evaluating the English teaching materials for Junior High school in Yogyakarta. The focus is on three aspects; (1) to evaluate the teachers' and students books based on macro and micro factors; (2) to describe how the teacher applies the knowledge of language resources in classroom context. (3) to explain the theoretical understanding (declarative knowledge) of English teacher on evaluation of English language resources.

\section{METHOD}

In this section, we describe how the search was conducted. This part composed of participant's selection, the setting, the data collection technique, instruments and finally how we analyzed data.

The participants were class seven English students with their teacher, in one of the Junior high School in Yogyakarta. The participants were purposive selected since the class had all facilities including technological devices such as projectors and laptop for students, and the students were in the first year of learning English language.

The research was conducted in one junior high school in Yogyakarta. The setting was selected because it was accessible to the researcher and the Junior High School was suitable since it is the class where most students begin studying English language. The school had good technological infrastructures such as wireless internet, projectors, ICT laboratory and laptop for all students. The availability of ICT devices was suitable to enhance Communicative Language Teaching Approach.

The data were collected through classroom observation, interview and document review, this triangulation technique was used to account for validity and reliability of data obtained. The instrument used were check list, semi structured interview guide and check list for language materials evaluation adapted from indicators discussed by McDonough, et al. (2012). Two Junior High School English books were evaluated. The English teachers guide book and student English book for Junior High School book class seven "Bahasa Inggris When English Rings a Bell".

The data were analyzed qualitatively through, data condensation, data display and drawing conclusion through verification. The data were analyzed following the techniques used to collect data and the objectives of the study.

\section{FINDINGS AND DISCUSSION}

In this part we present and discuss the findings. The findings will be presented according to data collection techniques. We begin with document review, observation and finally interview with the teacher.

\section{Document Review}

The two English books were used, one is student's book and the other is teacher's book. The analysis was done basing on some criteria adapted from McDonough, et al. (2012)who explained the macro and micro criteria for evaluation. Both books met most of the criteria for language materials. However, there are some criteria which the books did not meet. In this section we will discuss few best criteria and the few weaknesses of the books. 


$$
\text { LingTera, } 5 \text { (2), } 2018 \text { - } 157
$$

Godlove Elioth Kiswaga, Anita Triastuti

Tabel 1. The Findings from Teachers Book

\begin{tabular}{ll}
\hline No. & \multicolumn{1}{c}{ Macro } \\
\hline 1. & Appearance of the book \\
2. & The aims of learning \\
3. & Language used \\
4. & The sequence of the material \\
5. Type of the syllabus used \\
\\
6. Time table for meeting \\
7. $\quad$ The relationship between what is \\
\\
$\quad$ inside the book.
\end{tabular}

\section{Micro}

1. Contextualization of the content

2. Integration of the four skills

3. Grading system indicated in the book

4. Inclusion of discourse

5. Natural dialogue

6. Caters for different learning styles of learners

7. Technological aspects in the book

8. Cultural awareness

The appearance is good but it is written in Indonesian language Well stated suitable for communicative approach Mostly in Indonesian and sometimes code -mixing Sequence is good starts with greetings, socialization and other wider communicative aspects with various discourses. Well explained, it includes multiple of syllabuses; task based, content based, project based, teaching and learning cycles. These syllabuses are essential for communicative language approach.

The suggested time table is well organized based on the content. There is direct relationship between what is explained in the outline and the content inside the book, eg; the criteria for evaluation in page 16-20, match with the model of teaching in page 6 .

The content is well contextualized page 119 explaining about Indonesian environment, types of food, climate, animals. The four macro skills are well integrated in this book page 16-20 assessment of the four skills is explained well.

The grading system is well indicated in the book. It is also suitable to the teaching methodology indicated.

The book explains the assessment which goes beyond sentence and grammatical aspects, it includes discourse aspects in teaching and assessment tasks as indicated in page 16-20 The book includes natural dialogues contextualized to student's environment.

The book indicates various assignments and assessment which includes all learning styles.

Well treated the book emphasizes on the use of technology such as; google blog, e-mail, social media,facebook, kakao talk, whatsApp etc. Page 12

The materials in the book does not include some aspects of other cultures other than Indonesian culture.

Starting with good criteria, the teachers book shows different recommended strategies in teaching language through communicative approach, Example the teachers book on page, 11 , in the book shows, group work, pair work, project based, task based and role play as among the recommended learning activities, this shows that the learning activities are flexible to suit different types of syllabuses as it is mentioned by McDonough, et al. (2012, p. 13)

Second, the teacher's book shows that there is integration of the four macro language skills in language learning, in teachers book page, 16-20, these pages show how assessment is done by involving all the four macro skills such as; listening, presentation, writing and reading.

Third, the teacher's book shows the use of the global media in learning example in page 12 the book suggests the use of google, blog, e-mail, social media, yahoo messenger, facebook and twitter for study. This is very essential aspect in language learning in this global era, McDonough, et al. (2012) describes the importance of teaching materials to be interactive with the digital components and technology within and outside the class. This situation makes students to be connected with the global world.

Fourth, there is contextualized of the content in this book, the use of natural monologues and dialogues help the learners to understand well. Example can be shown in page, 119, where the guide book describes about the climate and the natural food, animals and other things found in Indonesia. This point is also supported by McDonough, et al. (2012) and Karimnia \& Jafari (2017).

However, there are some weaknesses in the books, first the teacher's book is in Indonesian language, this situation makes the teacher lack proper English terminologies to teach the students, as a result the teacher needs other books 


\section{LingTera, 5 (2), 2018 - 158}

\section{Godlove Elioth Kiswaga, Anita Triastuti}

to find the English terminologies when instructing the students what to do.

Second, the teacher's book does not include other aspects of other cultures rather than Indonesian culture. Including only Indonesian culture in teaching English may isolate the students from cultural awareness which is very essential aspect in this global era. It is important to know other cultures, however is not necessarily for the students to adapt those cultural elements. McDonough, et al. (2012) also suggest the inclusion of global culture of other speakers of English in teaching English to the students.

With consideration to the table above, the analysis of the student book shows that most of the macro and micro aspects are good for teaching English Language. Some of the few examples from the table will be discussed here.

First, the book shows the use of multiple of syllabuses as suggested by McDonough, et al. (2012). In student's book, we see the implementation of task based, project based, functional syllabus and problem based. This implementation is realized by the continuous tasks given to the student from the beginning to end of the book. In addition, the tasks are arranged from light to heavy. Moreover, the tasks are done in pear work, group, and individually. All the tasks are very important for communicative language approach.

Second, the integration of the four macro skills in teaching has been expressed well through the tasks in the book. All tasks indicated in the book make the student learn by practicing the four macro skills, listening, speaking, reading and writing. All tasks from pages, 4-200 apply the four macro language skills as it is stated in the instruction before the activities. Integrating the four skills as essential to make the students more communicative has been supported Rahman and Akhter (2017), Akram and Malik, (2010), Hinkel (2010), Klimova (2014), McDonough, et al. (2012), Sadiku (2015) and Tajzad and OstovarNamaghi (2014).

Tabel 2. The Findings from Students' Book

\begin{tabular}{|c|c|c|}
\hline No. & Indicators & Comments \\
\hline & Macro & \\
\hline 1. & Book cover and introduction & The cover is good but the introduction is in Indonesian language. \\
\hline 2. & The table of content & $\begin{array}{l}\text { The table of content is good starting from greetings to higher } \\
\text { communicative tasks. }\end{array}$ \\
\hline 3. & Pictures in the book & $\begin{array}{l}\text { The pictures in the book are good showing the wearing culture of } \\
\text { Indonesians. }\end{array}$ \\
\hline 4. & The content of the book & The content is suitable for students at the beginning level. \\
\hline 5. & The sequence of the material & $\begin{array}{l}\text { The sequence of the material is well since it starts with lower } \\
\text { communicative aspects to higher tasks like projects. }\end{array}$ \\
\hline 6. & Syllabus used in the book & $\begin{array}{l}\text { The book is the implementation of different syllabuses in } \\
\text { language teaching, eg. Task based, project based, problem based, } \\
\text { functional syllabus. }\end{array}$ \\
\hline 7. & $\begin{array}{l}\text { The aim of the material } \\
\text { Micro }\end{array}$ & To make the student communicate using English language. \\
\hline 1. & The application of technology & $\begin{array}{l}\text { In the book there is little interaction with the digital world. Does } \\
\text { not apply digital technology as indicated in the teacher`s book. }\end{array}$ \\
\hline 2. & Cultural awareness & $\begin{array}{l}\text { Only the Indonesian culture is emphasized in the book, no } \\
\text { interaction with other cultures in the world. }\end{array}$ \\
\hline 3. & $\begin{array}{l}\text { Contextualized of the learning } \\
\text { process }\end{array}$ & $\begin{array}{l}\text { The tasks given are communicative and contextualized with the } \\
\text { student's environment. Example page } 26 \text { changing their Identity } \\
\text { Card information into English. }\end{array}$ \\
\hline 4. & Integration of the four macro skills & $\begin{array}{l}\text { All the tasks involve the four macro skills interactively. Listen, } \\
\text { speaking, reading, writing }\end{array}$ \\
\hline 5. & Use of audiovisual materials & $\begin{array}{l}\text { There is no use of audio-visual materials since in all tasks the } \\
\text { student listen to their teachers who might not be good model in } \\
\text { pronunciation. }\end{array}$ \\
\hline 6. & Manner of doing tasks & $\begin{array}{l}\text { Tasks are done in groups, pair work and individually, this is well } \\
\text { recommended in communicative approach. }\end{array}$ \\
\hline 7. & Teaching grammar and vocabulary & $\begin{array}{l}\text { Grammar and vocabulary are integrated in social setting of } \\
\text { communication. Examples page } 166 \text { maps and names of places } \\
\text { in Indonesian are used in communicative teaching. }\end{array}$ \\
\hline
\end{tabular}




\section{LingTera, 5 (2), 2018 - 159 \\ Godlove Elioth Kiswaga, Anita Triastuti}

Third, the contextualization of the learning is well implemented in the student's book, contextualization of the materials is good to make the students understand better rather than using the artificial environment which are not suitable to the students. In this book, the tasks are well contextualized, for example on page 29, the students are given tasks to change their identity cards information from Indonesian to English, Also the names used throughout the book are Indonesian names, such as Rina, Yulia, Edo, Beni and so many others. Using familiar environment and names make the students understand better as they learn language.

Regardless of the positive comments about the student's book, there are some few negatives which a teacher should note and change them for effective teaching. First the introduction of the book is written in Indonesian language and only Indonesian culture is included in the book, therefore, this situation does not raise the intercultural awareness to the students. Students do not learn the culture of the target language and other English speakers. McDonough, et al. (2012) explained that it is important to include the cultures of other English speakers in teaching English language effectively in this global era.

Second, in the student book the listening activities show that the students should listen to the teacher while in the teacher's books it is suggested that video, audiovisual materials can be used. As a results, students listen to the teacher who is not good model for the pronunciation and other speaking aspects. It is better to listen to natural native English speakers through audiovisual materials so as to improve English language speaking skill. McDonough, et al. (2012) explain the importance of using digital technology to teach language to make the students integrated to the global world.

Third the student's book does not discuss about the global issues, this tendency will make the students to focus their thinking only in Indonesian context and they cannot be autonomous learners. From these few points selected as a sample for discussion concerning the books used in the class, it shows that some of the elements are good. However, the teacher has to adapt some of the things to make the learning better and suitable to the learner's context and global context.

\section{Classroom Observation}

After the discussion on the documents, the observation was done in class to see how the teacher uses the resources practically in classroom context. The teacher used the materials well in the classroom. However, the teaching was still teacher centered, and most of the time students were passive participants. The teaching and learning activities were not flexible to incurporate different types of syllabuses as mentioned by McDonough, et al. (2012) or in the teacher`s and student's books. Most of the time the teacher and students used Indonesian language. Therefore, students did not learn how to speak English through various activities as suggested in the teacher's book.

In addition, students did not work in pair or group instead each student worked independently. Also, the activities did not involve the four skills, only reading and writing were done, while listening was done by repetition of what the teacher was saying no audio-visual materials from native speakers were used, speaking also was done by repeating to the teacher. Hence, there was no creativity for integrating the four macro language skills. Teachers should be more creative to involve learners in language learning activities as shown in the teacher`s book, because the class has wireless and all students use laptop. In addition, there is projector and power point in class. The application of technology was manifested only by sending the assignment to their teachers through email and pictures showed on power point. Therefore, the teacher could teach language creatively with application of technology better than the way it was performed.

\section{Interview with the Teacher}

After analyzing the two books, then observe how the books are interpreted practically in classroom context. Finally the researcher and the teacher had a short interview related to English language learning resources and its implementation. This section discusses the teacher`s responses in the interview session.

The first question, when the teacher was asked whether the materials provided to teach language are enough.The teacher responded that, "yes, there are textbooks from the government but there are supplementary materials such as video, internet sources and other supplementary text which are added by me as the teacher based on the context of the learners".

This shows that the teacher has the knowledge of adding the materials basing on the context. Her ideas are supported by McDonough, et al. (2012). These scholars discussed the importance of evaluating the material before 
using them in order to make decision whether to adapt them basing on the context. Therefore, the teacher has the knowledge of adapting the text book by adding supplementary materials.

Second question was about the kind of materials she uses to teach language in the class, she answered that, "I use natural environment, real objects, making video to teach language in classroom context".

The response shows that the teacher knows the importance of contextualizing the learning process. These findings are supported by (Ahamed, 2017; McDonough, et al., 2012; Ürün, 2015) who emphasize on the importance of using different resources including technology to make the language learning more authentic and contextualized with the environment.

Third question was about the media used to teach language in class, when the teacher was asked about the media she uses to teach language, she responded that "I use computer, email, powerpoint, whatsApp and other audio-visual materials to make the students participate fully and become more creative in classroom".

This implies that the teacher is conscious with the use of social global media to motivate language learning. Different language researches support her response. Raghul and Rajkumar (2018) argue on the importance of using technology such as (CALL) computer assisted language learning, MALL (mobile assisted Language Learning, multimedia such as audio, video, image graphic, software, projectors and social media such as whatsapp, face book, instergram and twitter to integrate the four skills in language teaching. Similarly, Ürün (2015) supports this idea by explaining the importance of audio-visual materials such as video, power point slides and the use of computer are essential to integrate the four skills in language learning.

Fourth, when the teacher was asked about the activities given to students she responded "Reading dialogue, writing scripts, recording video, listening to the video, presenting and commends other presentations".

This implies that the teachers has the knowledge of task based language learning, since task based involves learning language through integration of the four skills. Similarly, learning by integrating the four skills is discussed by many scholars of language teaching in this global era. Most of the scholars discussed this because we are in Communicative Language Teaching Approach currently. This question is related to the other question which aimed at investigating whether the four macro skills are integrated in language learning and which activities the teacher uses to integrate the four skills. The response was; "Yes, I integrate the four skills in language learning, the activities involving the four skills are Listening to dialogue, reading the dialogue and practice in speaking, writing the transcript of the dialogue make video, listen the video to the class and give comments".

From the explanation above we can deduce that the teacher knows the importance of integrating the four macro skills. In addition to that, she can design the activities to integrate the four skills basing on classroom context. This point is also discussed by (Akram \& Malik, 2010; Hinkel, 2010; Klimova, 2014; McDonough, et al., 2012); Rahman \& Akhter, 2017; Raghul \& Rajkumar, 2018; Sadiku, 2015; Ürün, 2015; Tajzad \& Ostovar-Namaghi, 2014). These scholars discuss on the importance and how to integrate the macro skills in language learning by giving different constructive views. However, some of the views are similar with the ideas given by the teacher in the interview.

\section{CONCLUSION}

After the discussion of the findings from three sources; review of the two books used by the teacher in class, observation done in classroom and interview with the teacher, this section gives the conclusion and recommendations. First, the findings from the documents show that most of the materials in the text match with the learner's context. However, some changes are needed especially; more English materials are needed for the teachers and students to practice English. The audiovisual English materials from native speakers should be added to student's book since student listen to the Indonesian teacher as a model.

Second the findings from observation show that, changes are needed to make teaching more effective. For example, teaching and learning activities are still teacher centered. The students do not interact in pair or group during class activities. They are not involved in role play, project based or task based activities. Moreover, only reading and writing skills are done by the students in class. Therefore, the teacher needs to integrate the four skills in classroom learning since the class has wireless internet, power point and projectors. Hence, teaching and learning language could utilize this technology to integrate the four skills as it is suggested in the teacher`s book and her responses from interview. 


\section{LingTera, 5 (2), 2018 - 161}

\section{Godlove Elioth Kiswaga, Anita Triastuti}

Third, the findings from the interview show that the teacher has the knowledge of what is needed to be done in classroom situation. All responses from interview are relevant to the global language teaching approach. It shows also the teacher has the knowledge about how to integrate different syllabuses in language through different activities, she could explain well the importance and how to integrate the four skills. She could also explain the importance of adapting materials by adding supplementary materials to make the learning more effective. However, the teacher could not implement the knowledge she has as it was observed practically in classroom.

It is recommended that the teacher should apply the knowledge and creativity she has based on the interview responses in actual classroom practices. She has also to use the good recommendation from the teacher's book and adapt the materials by adding more materials and use them in real classroom practice to make the teaching and learning language more effective and efficient. With the practical implementation of the creativity she showed in interview, the teacher will make students more creative, collaborative, critical thinker and communicative. Hence, students will sustain this global language learning era.

\section{REFERENCES}

Rahman, S., \& Akhter, A. (2017). Skills teaching in ESL classroom: Discrete vs integrated. International Journal of English Language Teaching, 5 (4), 32-39.

Ahmed, S. (2017). Authentic ELT materials in the language classroom: An overview. Journal of Applied Linguisfics and Language Research, 4(2), 181-202.

Akram, A., \& Malik, A. (2010). Integration of language learning skills in second language acquisition. International Journal of Arts and Sciences, 3(14), 231240.

Pusat Kurikulum dan Perbukuan Balitbang, Kemdikbud. (2016). Buku guru bahasa Inggris when English rings a bell ( $3^{\text {rd }}$ ed.). Jakarta.

Pusat Kurikulum dan Perbukuan, Balitbang, Kemdikbud. (2016). Bahasa Inggris When English Rings a bell. Jakarta.
Hinkel, E. (2010). Integrating the four skills: Current and historical perspectives. In (Ed.), The Oxford Handbook of Applied Linguistics: Oxford University Press, Retrieved from http://www.oxfordhandbooks.com/view/1 0.1093/oxfordhb/9780195384253.001.000 1/oxfordhb-9780195384253-e-8.

Karimnia, A., \& Jafari, F. M. (2017). Critical ESP textbook evaluation: The case of visual arts textbook. Sustainable Multilingualism, 11(1), 219-236.

Klimova, B. F. (2014). Detecting the development of language skills in current English language teaching in the Czech Republic. Procedia - Social and Behavioral Sciences, 158, 85-92. https://doi.org/10.1016/J.SBSPRO.2014.1 2.037

McDonough, J., Shaw, C., \& Masuhara, H. (2012). Materials and methods in ELT: a teacher's guide. Wiley-Blackwell.

Raghul, E., \& Rajkumar, S. (2018). Integrating technology into English language teaching and learning: Possibilities and challenges, Journal of Social Sciences, 13 (1), 206$2012 . \quad$ doi: https://doi.org/10.3923/sscience.2018.206 .212

Sadiku, L. M. (2015). The importance of four skills reading, speaking, writing, listening in a lesson hour. European Journal of Language and Literature, 1(1), 29-31.

Tajzad, M., \& Ostovar-Namaghi, S. A. (2014). Exploring EFL learners' perceptions of integrated skills approach: A grounded theory. English Language Teaching, 7(11), 92-98.

Tomlinson, B. (2011). Material development in language teaching $\left(2^{\text {nd }}\right.$ ed). Cambridge: Cambridge University Press.

Ürün, M. F. (2015). Integration of technology into language teaching: A comparative review study. Journal of Language Teaching and Research, 7(1), 76-87. 